\title{
A PROSECUTION TOO FAR? REFLECTIONS ON THE ACCOUNTABILITY OF HEADS OF STATE UNDER INTERNATIONAL CRIMINAL LAW
}

\author{
Steven Freeland ${ }^{*}$
}

The recent issue by the International Criminal Court (ICC) of an arrest warrant against Omar Al
Bashir, the President of Sudan, for alleged war crimes and crimes against humanity, represents the
first time that the ICC has acted in such a way against an incumbent Head of State. It has renewed
the debate about the potential international criminal responsibility of Heads of State and has led to
strong opinions both for and against such actions. Yet, the prosecution of Heads of State is by no
means a new phenomenon, and its continued use represents an important element in the
internationalisation of justice that has gained renewed emphasis over the past two decades. This
article offers some thoughts and reflections on several key issues associated with this debate,
focusing particularly on the political, legal and historical dimensions that have combined to allow
for the prosecution under international criminal law of any person, irrespective of their official
capacity. It also examines the important role in this regard for the ICC, the world's first permanent
international criminal tribunal, as well as the increasing range of prosecutions now taking place
within national jurisdictions, as the period of impunity in relation to the commission of international
crimes that had existed for several decades up to the 1990 s has come to an end.

\section{INTRODUCTION - RECENT PROSECUTIONS}

On 26 October 2009, the trial of Radovan Karadžić, the former President of Republika Srpska, began before the International Criminal Tribunal for the former Yugoslavia (ICTY). Karadžić, who had initially been indicted by the ICTY Prosecutor in July 1995, has been charged with allegedly

* Professor of International Law, University of Western Sydney, Australia; Visiting Professor of International Law, University of Copenhagen, Denmark; Visiting Professional, the International Criminal Court, The Hague, The Netherlands. This article was written in November 2009 and represents the author's personal views. 
having committed acts constituting genocide, crimes against humanity and violation of the laws or customs of war. ${ }^{1}$ His trial is expected to last for a considerable period of time.

The ICTY has previously prosecuted other former Heads of State. Biljana Plavšić, former Serbian Representative to the collective Presidency of Bosnia and Herzegovina and member of the collective and expanded Presidencies of the Bosnian Serb Republic (which subsequently became Republika Srpska), pleaded guilty to various counts of crimes against humanity and was sentenced in 2003 to 11 years' imprisonment. ${ }^{2}$

Probably the most (in)famous trial undertaken by the ICTY involved the prosecution of Slobodan Milošević, the former President of Serbia and of the Federal Republic of Yugoslavia. Milošević was taken into custody by the ICTY in June 2001 and his trial relating to charges of genocide and crimes against humanity commenced in February 2002. These proved to be lengthy and complex proceedings. ${ }^{3}$ Indeed, Milošević died in March 2006 before the trial could be completed, prompting strong criticism from some quarters regarding the conduct of international criminal trials. $^{4}$

The other ad hoc international criminal tribunal established in the early 1990 s by the United Nations Security Council (UNSC), the International Criminal Tribunal for Rwanda (ICTR), ${ }^{5}$ has

1 For details of the charges against Radovan Karadžić, as well as background information relating to his trial, see Communications Service of the International Tribunal for the former Yugoslavia (ICTY) "Radovan Karadžić" <www.icty.org>. The ICTY was formally established pursuant to Resolution on the Tribunal (Former Yugoslavia) SC Res 827 at [2], S/RES/827 (1993):

... for the sole purpose of prosecuting persons responsible for serious violations of international humanitarian law committed in the territory of the former Yugoslavia between 1 January 1991 and a date to be determined by the Security Council upon the restoration of peace.

The text of the Statute of the ICTY (ICTY Statute) may be found in Report of the Secretary-General pursuant to Paragraph 2 of Security Council Resolution 808 (1993) S/25704, annex.

2 For details of the charges against Biljana Plavšić, as well as background information relating to her conviction, see Communications Service of the ICTY "Biljana Plavšić" <www.icty.org>. She has recently been granted early release from prison in Sweden and has returned to Serbia.

3 For a comprehensive description of the proceedings against Slobodan Milošević in the ICTY, see Gideon Boas The Milošević Trial: Lessons for the Conduct of Complex International Criminal Proceedings (Cambridge University Press, Cambridge, 2007).

4 For a discussion of these criticisms, see Steven Freeland "The Internationalization of Criminal Justice" in Stephan Hobe (ed) Globalisation - the State and International Law (Franz Steiner Verlag, Stuttgart, 2009) 117 .

5 The Statute of the International Criminal Tribunal for Rwanda (ICTR) (ICTR Statute) provides that the ICTR has "the power to prosecute persons responsible for serious violations of international humanitarian law committed in the territory of Rwanda and Rwandan citizens responsible for such violations committed in the territory of neighbouring States, between 1 January 1994 and 31 December 1994": Resolution on the 
also convicted a former Head of State. Jean Kambanda, the former Prime Minister of the interim government of Rwanda during the 1994 genocide, had initially pleaded guilty in May 1998 to genocide and crimes against humanity and was sentenced to life imprisonment. ${ }^{6}$ His attempt to retract his admission of guilt and to appeal this sentence was rejected by the Appeals Chamber in October 2000. ${ }^{7}$ He was transferred to Mali in December 2001, where he is now serving his sentence.

Each of these prosecutions seeks to make former Heads of State accountable under international criminal law for their actions while in power. The issue of Head of State responsibility has more recently been given far greater prominence when, in March 2009, Pre-Trial Chamber I of the International Criminal Court (ICC) issued an arrest warrant for President Omar Al Bashir, the current Head of State of Sudan. ${ }^{8}$ In issuing the arrest warrant, the Pre-Trial Chamber had concluded that there were reasonable grounds to believe that President Bashir was criminally responsible on five counts of crimes against humanity and two counts of war crimes. ${ }^{9}$

The decision of the Pre-Trial Chamber was met with a mixture of strong support from large sections of the international community and disappointment from various Arab and African countries $^{10}$ and a number of aid agencies. It was reported that, a few days after the decision of the Pre-Trial Chamber, the government of Sudan expelled 13 humanitarian international nongovernmental organisations and three local non-governmental organisations from Darfur, on the grounds that they had communicated information to the ICC. The government in Sudan continues to

Establishment of an International Tribunal and Adoption of the Statute of the Tribunal SC Res 955 annex at art 1, S/RES/955 (1994).

6 The Prosecutor $v$ Jean Kambanda (Judgment and Sentence) (4 September 1998) ICTR 97-23-S (Trial Chamber, ICTR).

7 Jean Kambanda v The Prosecutor (Judgment) (19 October 2000) ICTR 97-23-A (Appeals Chamber, ICTR).

8 International Criminal Court (ICC) Warrant of Arrest for Omar Hassan Ahmad Al Bashir, The Prosecutor $v$ Omar Hassan Ahmad Al Bashir ('Omar Al Bashir') (Case No ICC-02/05-01/09, Pre-Trial Chamber 1, 4 March 2009) <www.icc-cpi.int>.

9 ICC Decision on the Prosecution's Application for a Warrant of Arrest against Omar Hassan Ahmad Al Bashir, The Prosecutor v Omar Hassan Ahmad Al Bashir ('Omar Al Bashir') (Case No ICC-02/05-01/09, Pre-Trial Chamber 1, 4 March 2009) <www.icc-cpi.int>. In handing down its decision, the Pre-Trial Chamber (by a two-to-one majority) concluded that, at this stage, there were not reasonable grounds to also include charges of genocide, although it left open the possibility for the Prosecutor to submit further evidence in the future to support such a charge. At the time of writing this article, the Pre-Trial Chamber decision is the subject of an appeal to the Appeals Chamber of the ICC: see for example ICC Decision on the "Prosecution Request for an Extension of the Page Limit for its Document in Support of Appeal against the 'Decision on the Prosecution's Application for a Warrant of Arrest against Omar Hassan Ahmad Al Bashir'", The Prosecutor v Omar Hassan Ahmad Al Bashir ('Omar Al Bashir') (Case No ICC-02/05-01/09 OA, Appeals Chamber 1, 3 July 2009) <www.icc-cpi.int>.

10 See for example "Botswana condemns AU resolution on Sudan's Bashir" (7 July 2009) Reuters $<$ www.af.reuters.com>. 
assert that it will not cooperate with the ICC in respect of the charges against President Bashir, ${ }^{11}$ as well as those in relation to arrest warrants previously issued by the ICC against two other Sudanese nationals. $^{12}$

In addition, both the African Union and the Organisation of Islamic States have made several representations to the UNSC, asking that it defer the work of the ICC in Darfur pursuant to Article 16 of the Rome Statute of the ICC (Rome Statute). ${ }^{13}$

These events further highlight the complications associated with the criminal prosecution of Heads of State at the international level; an issue that raises many questions. This article, while not purporting to be comprehensive in this regard, offers some thoughts and reflections as to several specific dimensions to this debate. It first describes the historical background to the (potential) prosecution of Heads of State in the various mechanisms of international justice, created only in the 20th century. It then examines the relevant legal and political dimensions to this issue, indicating the inherent inter-relationship between these two factors.

The article then turns to the most significant of the mechanisms of international justice thus far established, the permanent ICC, and describes its jurisdictional constraints and relationship with the UNSC - by virtue of which it has the competence to prosecute the Head of State of Sudan, a nonState party to the Rome Statute. Following on from this, the article offers some preliminary thoughts - which undoubtedly should and will be the subject of future research - as to how such actions might ultimately be viewed in the context of the possible "goals" of the ICC, measured against any potentially appropriate "criteria of success" for the Court. Naturally, such thoughts can only be of a perfunctory nature at this early stage in the activities of the ICC, with a proper consideration of its legacy, and the role that prosecution of Heads of State may play in this, only really possible perhaps in several decades from now. The article concludes with some comments regarding the way forward, suggesting that the prosecution of Heads of State, at both the international but also the national level, represents an integral and important element in the "internationalisation of justice" that we have now embarked upon.

11 See for example "Dancing Bashir scoffs at Darfur warrant" (5 March 2009) BBC News $<$ http://news.bbc.co.uk $>$.

12 These are in relation to Ahmad Muhammad Harun (Ahmad Harun) and Ali Muhammad Ali Abd-AlRahman (Ali Kushayb): for details, see ICC "Darfur, Sudan" < www.icc-cpi.int>.

13 Rome Statute of the International Criminal Court (opened for signature 17 July 1998, entered into force 1 July 2002) [Rome Statute]. Article 16 of the Rome Statute provides as follows:

No investigation or prosecution may be commenced or proceeded with under this Statute for a period of 12 months after the Security Council, in a resolution adopted under Chapter VII of the Charter of the United Nations, has requested the Court to that effect; that request may be renewed by the Council under the same conditions. 


\section{ISSUES ASSOCIATED WITH PROSECUTING HEADS OF STATE}

\section{A Historical Dimensions}

As indicated above, the (attempted) prosecution of a Head of State is not without precedent there has been a number of historically interesting examples. In 1642, for instance, Charles I of England was tried and sentenced to death for various "crimes" he committed while King. This was the first time that a (former) Head of State was prosecuted in a court of law in relation to (alleged) crimes committed while in such a position. ${ }^{14}$

At the conclusion of World War I, the Treaty of Versailles ${ }^{15}$ provided for the prosecution of "persons accused of having committed acts in violation of the laws and customs of war". ${ }^{16}$ The Allied and Associated Powers publicly arraigned Wilhelm II of Hohenzollern, formerly the German Emperor, "for a supreme offence against international morality and the sanctity of treaties". ${ }^{17}$ The Treaty of Versailles provided for a special international tribunal to be constituted, comprising judges from the United States of America, Great Britain, France, Italy and Japan, to try the Emperor.

However, by the time the Treaty of Versailles was in force, the Emperor had already sought refuge in the Netherlands, which did not agree to surrender him for prosecution, on the basis that it regarded itself as "a land of refuge for the vanquished in international conflicts". ${ }^{18}$ A trial in absentia was considered futile and, as a result, the international tribunal was not established.

14 For a detailed historical account of the trial of Charles I, as well as the background leading up to the trial, see Geoffrey Robertson The Tyrannicide Brief: The Story of the Man who sent Charles I to the Scaffold (Chatto and Windus, London, 2005).

15 Treaty of Peace between the Allied and Associated Powers and Germany (signed 28 June 1919, entered into force 10 January 1920).

16 Ibid, art 228.

17 Ibid, art 227. On the first day of World War I, the German Emperor had reportedly written in a letter to the Austrian Emperor:

Everything must be drowned in fire and blood. It is essential to kill men and women, children and old men, not to leave standing a single house or a single tree. By these terrorist methods, the only methods capable of frightening such a degenerate people as the French, the war will be ended in less than two months: while if I take considerations of humanity into account, the war will last several years.

See Nina Jørgensen The Responsibility of States for International Crimes (Oxford University Press, Oxford, 2000) at 4 and the corresponding footnote.

18 Jørgensen, above n 17 , at 7. 
This situation changed following the end of World War II. International Military Tribunals were established by the victorious powers in Nuremberg ${ }^{19}$ and Tokyo. ${ }^{20}$ The agreement among the Allies to establish these Tribunals to try senior military and political leaders from the defeated German and Japanese wartime regimes only came late in the piece. With the exception of the United States, they had initially been of the opinion that an international judicial process was not appropriate. This was only partially due to the fact that such an approach was largely unprecedented; it also stemmed from their more "extreme" views as to how such persons should be brought to account. The British government had, for example, instituted a formal policy of "summary execution" of enemy leaders in 1943, which remained in place until the end of the war. ${ }^{21}$

In the end, however, the viewpoint of the United States - that a transparent international judicial process was the most appropriate mechanism to deal with such persons - prevailed, and these Tribunals were established with a mandate and procedural framework that largely reflected western notions of justice. $^{22}$

At Nuremberg, senior government officials were put on trial. The Charter of the Nuremberg Military Tribunal ${ }^{23}$ provided for the prosecution of Heads of State. Indeed, there is little doubt that, had he survived the war, Hitler himself would have also been brought before this legal process. Article 7 of the Charter of the Nuremberg Military Tribunal stipulated that "[t]he official position of defendants, whether as Heads of State or responsible officials in Government Departments, shall not be considered as freeing them from responsibility or mitigating punishment."24

This was also the position under the Charter of the Tokyo Military Tribunal, ${ }^{25}$ although the decision was made by the United States not to indict Emperor Hirohito or any member of the royal family. However, various other leading government officials, including former Prime Minister Hideki Tojo, were prosecuted and ultimately found guilty by the Tokyo Military Tribunal.

19 International Military Tribunal for the Trial of the German Major War Criminals at Nuremberg (Nuremberg Military Tribunal).

20 International Military Tribunal for the Trial of the Major War Criminals in the Far East (Tokyo Military Tribunal).

21 Richard Overy "The Nuremberg trials: international law in the making" in Philippe Sands (ed) From Nuremberg to The Hague: The Future of International Criminal Justice (Cambridge University Press, Cambridge, 2003) 1 at 3-4.

22 Ibid, at 4.

23 Charter of the Nuremberg International Military Tribunal, annexed to the 1945 London Agreement for the Establishment of an International Military Tribunal (8 August 1945) [Nuremberg Military Tribunal Charter].

24 Ibid, art 7.

25 Charter of the International Military Tribunal for the Far East (19 January 1946) [Tokyo Military Tribunal Charter], art 6. 
Despite their flaws, what was perhaps most striking about this entire process of international criminal justice, particularly when compared to any earlier practical attempts to criminalise acts committed during warfare, was that the Nuremberg and Tokyo Military Tribunals applied international law doctrines and concepts to judge the acts of those accused of such crimes. Although they were not in identical terms, the respective Charters of these two Military Tribunals specified the definitions of a number of "international crimes". ${ }^{26}$ These were very significant steps in the development of international criminal justice, including for crimes committed by Heads of State.

In December 1946, the United Nations General Assembly (UNGA) affirmed "the principles of international law recognised by the Charter of the Nürnberg Tribunal and the judgment of the Tribunal" and directed the United Nations International Law Commission (ILC) to formulate those

26 The crimes within the jurisdiction of the Nuremberg Military Tribunal, as set out in art 6 of the Nuremberg Military Tribunal Charter, were:

(a) Crimes Against Peace: namely, planning, preparation, initiation or waging of a war of aggression, or a war in violation of international treaties, agreements or assurances, or participation in a common plan or conspiracy for the accomplishment of any of the foregoing;

(b) War Crimes: namely, violations of the laws or customs of war. Such violations shall include, but not be limited to, murder, ill-treatment or deportation to slave labor or for any other purpose of civilian population of or in occupied territory, murder or ill-treatment of prisoners of war or persons on the seas, killing of hostages, plunder of public or private property, wanton destruction of cities, towns or villages, or devastation not justified by military necessity;

(c) Crimes Against Humanity: namely, murder, extermination, enslavement, deportation, and other inhumane acts committed against any civilian population, before or during the war; or persecutions on political, racial or religious grounds in execution of or in connection with any crime within the jurisdiction of the Tribunal, whether or not in violation of the domestic law of the country where perpetrated.

The crimes within the jurisdiction of the Tokyo Military Tribunal, as set out in art 5 of the Tokyo Military Tribunal Charter, were:

(a) Crimes Against Peace: namely, the planning, preparation, initiation or waging of a declared or undeclared war of aggression, or a war in violation of international law, treaties, agreements or assurances, or participation in a common plan or conspiracy for the accomplishment of any of the foregoing;

(b) Conventional War Crimes: namely, violations of the laws or customs of war;

(c) Crimes Against Humanity: namely, murder, extermination, enslavement, deportation, and other inhumane acts committed against any civilian population, before or during the war, or persecutions on political or racial grounds in execution of or in connection with any crime within the jurisdiction of the Tribunal, whether or not in violation of the domestic law of the country where perpetrated. Leaders, organizers, instigators and accomplices participating in the formulation or execution of a common plan or conspiracy to commit any of the foregoing crimes are responsible for all acts performed by any person in execution of such plan. 
principles for the purposes of codification. ${ }^{27}$ The "Nuremberg Principles" were adopted by the ILC and presented to the UNGA in $1950 .^{28}$ They were soon considered to reflect customary international law. Principle III provided that:

The fact that a person who committed an act which constitutes a crime under international law acted as Head of State or responsible government official does not relieve him from responsibility under international law.

This was also reflected in the terms of the 1948 Genocide Convention. ${ }^{29}$ Already in its first session in 1946, the UNGA had affirmed that "genocide is a crime under international law"; this being before the crime itself had been formally defined. ${ }^{30}$ Article IV of the 1948 Genocide Convention provided that: "[p]ersons committing genocide or any of the other acts enumerated in article III shall be punished, whether they are constitutionally responsible rulers, public officials or private individuals". ${ }^{31}$

These sentiments have also been reflected in the respective statutes of those mechanisms of international criminal justice that have been established since the $1990 \mathrm{~s}^{32}$ In the case of the ICC, for example, Article 27 of the Rome Statute provides as follows: ${ }^{33}$

1. This Statute shall apply equally to all persons without any distinction based on official capacity. In particular, official capacity as a Head of State or Government, a member of a Government or parliament, an elected representative or a government official shall in no case exempt a person from criminal responsibility under this Statute, nor shall it, in and of itself, constitute a ground for reduction of sentence.

27 Resolution on the Affirmation of the Principles of International Law Recognized by the Charter of the Nürnberg Tribunal GA Res 95 (I), UN GOAR, 1st sess, 55th plen mtg (1946).

28 See for example Formulation of the Nürnberg Principles GA Res 488 (V), UN GOAR, 5th sess, 320th plen $\operatorname{mtg}(1950)$.

29 Convention on the Prevention and Punishment of the Crime of Genocide (opened for signature 9 December 1948, entered into force 12 January 1951) [1948 Genocide Convention].

30 Resolution on the Crime of Genocide GA Res 96 (I), UN GOAR, 1st sess, 55th plen mtg (1946) at [4]. Paragraphs 1, 2 and 4 of this Resolution referred to genocide as "a denial of the right of existence of entire human groups", irrespective of whether the actions were "committed on religious, racial, political or any other grounds". The definition of genocide in the 1948 Genocide Convention does not include a "political" group, but does include "national" and "ethnical" groups.

311948 Genocide Convention, above n 29, art 4.

32 See for example ICTY Statute, above n 1, art 7(2); ICTR Statute, above n 5, art 6(2).

33 Rome Statute, above n 13, art 27 
2. Immunities or special procedural rules which may attach to the official capacity of a person, whether under national or international law, shall not bar the Court from exercising its jurisdiction over such a person.

Notwithstanding the important principles relating to international criminal responsibility that emerged from the jurisprudence of the International Military Tribunals, as reflected in the Nuremberg Principles, there nevertheless followed a period of impunity, stemming from the advent of the Cold War in the 1940s. ${ }^{34}$

The situation has once again changed since the early 1990s. At that time, the shackles of the Cold War were loosened, and the UNSC was able to play a more active role in addressing these crimes, albeit after the fact. Faced with the widespread genocide in Rwanda ${ }^{35}$ and acts amounting to crimes against humanity, war crimes and, in the case of the Srebrenica massacre, genocide ${ }^{36}$ in the Former Yugoslavia, the UNSC, acting under its powers pursuant to Chapter VII of the United Nations Charter, ${ }^{37}$ established the ICTY and ICTR to prosecute the perpetrators of serious crimes committed during those conflicts.

Since then, various other international and "internationalised" criminal tribunals and courts have been established in relation to conflicts in Cambodia, ${ }^{38}$ Sierra Leone ${ }^{39}$ and East Timor, ${ }^{40}$ and the

34 See discussion below at D Political Dimensions.

35 See for example The Prosecutor v Jean-Paul Akayesu (Judgment) (2 September 1998) ICTR-96-4-T (Trial Chamber, ICTR).

36 See for example The Prosecutor v Radislav Krstić (Judgment) (2 August 2001) IT-98-33-T (Trial Chamber, ICTY), affirmed by The Prosecutor v Radislav Krstić (Judgment) (19 April 2004) IT-98-33-A (Appeals Chamber, ICTY). See also Case Concerning the Application of the Convention on the Prevention and Punishment of the Crime of Genocide (Bosnia and Herzegovina v Serbia and Montenegro) (Judgment) [2007] ICJ Rep 1 at [297].

37 Chapter VII of the Charter of the United Nations, arts 39-51, gives the United Nations Security Council (UNSC) certain powers with respect to "Threats to the Peace, Breaches of the Peace, and Acts of Aggression": Charter of the United Nations, ch 7, title. This was the first time that these powers had been used to establish ad hoc international criminal tribunals. In early cases before each of the ad hoc tribunals, it had been alleged that they were established unlawfully by the UNSC. These claims were dismissed: see Decision on Defence Motion for Interlocutory Appeal on Jurisdiction (The Prosecutor v Duško Tadić) (2 October 1995) IT-94-1 (Appeals Chamber, ICTY); Decision on the Defence Motion on Jurisdiction (The Prosecutor v Joseph Kanyabashi) (18 June 1997) ICTR-96-15-T (Trial Chamber, ICTR).

38 The Extraordinary Chambers in the Courts of Cambodia were established by the Agreement between the United Nations and the Royal Government of Cambodia dated June 2003 concerning the Prosecution under Cambodian Law of Crimes Committed during the Period of Democratic Kampuchea: see Resolution on the Khmer Rouge Trials GA Res 57/228 B, A/RES/57/228 (2003).

39 Pursuant to Resolution on the Situation in Sierra Leone SC Res 1315 at [3], S/RES/1315 (2000), the Secretary-General of the United Nations was enjoined by the UNSC to negotiate an agreement with the government of Sierra Leone to create an independent special court to prosecute those "persons who bear the greatest responsibility" for serious violations of international humanitarian law and Sierra Leonean law 
UNSC has more recently established a tribunal to investigate the assassination of former Lebanese Prime Minister Rafik Hariri in February 2005. ${ }^{41}$

The past 15 years have thus been marked by the development of a diverse range of mechanisms intended to address international crimes and promote and protect fundamental human rights, specifically in response to both international and (increasingly) internal conflicts. The establishment and operation of these various mechanisms of international justice represent a landmark shift in international legal regulation and jurisdiction, from an era of impunity towards recognition of the need for legal accountability for the most serious crimes of concern to the international community as a whole.

The underlying element in this evolving process of the "internationalisation" of justice is the widely expressed determination of the international community to "put an end to impunity for the perpetrators of these crimes". ${ }^{42}$ This is predicated on two key elements. The first of these is the establishment of these various international and internationalised legal mechanisms as a means of contributing to the prevention of such crimes in the future. ${ }^{43}$ Each of these tribunals and courts involves differing structures and jurisdictional mandates, depending upon the particular circumstances involved. Yet, in keeping with the principles that have developed, each allows for the prosecution of a Head of State where appropriate.

The development of these mechanisms co-exists with the other important element in this process of internationalisation - the adoption by States of their responsibilities to address gross violations of human rights, even when or if perpetrated by the Head of State. As the international system of criminal justice evolves, national governments can no longer ignore the moral imperative to recognise these crimes within their own domestic legal systems. A significant number of parties to the Rome Statute, including Australia and New Zealand, have recently "upgraded" their domestic

committed in the territory of Sierra Leone since 30 November 1996. The Special Court for Sierra Leone was established on 16 January 2002: see Statute of the Special Court for Sierra Leone, annexed to the Agreement Between the United Nations and the Government of Sierra Leone on the Establishment of a Special Court for Sierra Leone (adopted 16 January 2002, entered into force 12 April 2002).

40 The Special Panels for Serious Crimes in Timor-Leste were established by the United Nations Transitional Administration in Timor-Leste (UNTAET) on 6 June 2000: Regulation on the Establishment of Panels with Exclusive Jurisdiction over serious Criminal Offences UNTAET/REG/2000/15 (2000). The UNTAET was created by Resolution on the Situation in East Timor SC Res 1272, S/RES/1272 (1999).

41 Resolution on the Situation in the Middle East SC Res 1757, S/RES/1757 (2007). See Alberto Costi "The Hariri Tribunal" (2007) 13 RJP 169; "Hariri court opens at The Hague" (1 March 2009) BBC News $<$ http://news.bbc.co.uk>. See also Special Tribunal for Lebanon website <www.stl-tsl.org>.

42 Rome Statute, above n 13, preamble at [5].

43 For a detailed assessment of the role of the "internationalised" or "hybrid" courts, see Alberto Costi "Hybrid Tribunals as a Viable Transitional Justice Mechanism to Combat Impunity in Post-Conflict Situations" (2006) 22 NZULR 213. 
criminal codes to ensure that their national courts have competence and jurisdiction in relation to the crimes of genocide, war crimes and crimes against humanity, as defined in the Rome Statute. ${ }^{44}$ In many cases, this in itself represents a very significant step forward in the reinforcement of fundamental international legal norms. ${ }^{45}$

Among many things, one very important consequence of this process has been with respect to the accountability of Heads of State. Both international criminal justice and prosecution by national courts are directed towards "those responsible" 46 for the commission of gross violations of human rights. In many cases, crimes of the magnitude of those that fall within the jurisdiction of the mechanisms of international justice are perpetrated in complex and volatile contexts by organised and multifaceted structures. As such, they could never have been carried out without the support, organisation and resources of the State itself - led by a Head of State.

As a result of the effects of this internationalisation of the justice process, whereas Heads of State would have once regarded themselves as above the law, this is no longer the case. In addition to those referred to earlier, an increasing number of other (former) Heads of State have been the subject of criminal prosecutions, either in other internationalised tribunals or under national law. These include Augusto Pinochet (Chile), Saddam Hussein (Iraq), Alberto Fujimori (Peru), Charles Taylor (Liberia) ${ }^{47}$ and Hissene Habre (Chad). ${ }^{48}$ Indeed, in late 2009, Argentina's last military

44 Following ratification of the Rome Statute, the Australian Parliament enacted both the International Criminal Court Act 2002 (Cth) and the International Criminal Court (Consequential Amendments) Act 2002 (Cth) which, among other things, provided for cooperation between the Court and the Australian government and, more notably, introduced the crimes defined in the Rome Statute into Australian domestic law. New Zealand implemented the Rome Statute into its domestic laws through the International Crimes and International Criminal Court Act 2000. For a discussion of the New Zealand legislation, see Treasa Dunworth "The International Crimes and International Criminal Court Act 2000 (NZ): A Model for the Region?" in Neil Boister and Alberto Costi (eds) Regionalising International Criminal Law in the Pacific (New Zealand Association for Comparative Law, Wellington, 2006) 145.

45 For example, in the case of Australia, this implementing legislation was both significant and symbolic, given that Parliament had previously failed to effectively implement the 1948 Genocide Convention into domestic law, with the result that it had been very difficult to assert that a crime of genocide existed under Australian law: see for example Nulyarimma $v$ Thompson (1999) 165 ALR 621, where the Full Court of the Federal Court held, by majority, that rules of customary international law making genocide a crime were not part of Australian common law. As such, the ratification of the Rome Statute placed Australia in a position where it had to accept - albeit perhaps for pragmatic reasons - the inevitability that crimes such as genocide and crimes against humanity are and should be recognised as fundamental elements of its domestic criminal code.

46 Rome Statute, above n 13, preamble at [6].

47 The trial of Charles Taylor is currently in progress before the Special Court for Sierra Leone: for details, see Special Court for Sierra Leone website <www.sc-sl.org $>$.

48 See also International Court of Justice "Questions relating to the Obligation to Extradite or Prosecute (Belgium v Senegal)" (press release, 28 May 2009) <www.icj-cij.org>. 
President (1982-1983), Reynaldo Bignone, went on trial before a national court on charges relating to torture and human rights violations. ${ }^{49}$ No doubt, other leaders are currently within the sights of the mechanisms of international and national justice.

In the case (in particular) of the international mechanisms of international justice, the reality is that they have not been created to prosecute all perpetrators of international crimes. The practicalities of time, resources and their respective jurisdictional limitations mean that, at best, they can only be selective in their prosecutions. Indeed, this is the reason why a far greater responsibility for prosecution is now placed on national jurisdictions, particularly by way of the system of "complementarity" that operates under Article 17 of the Rome Statute. Having said this, the international courts and tribunals can and perhaps should lead the way, at least symbolically, in demonstrating that even the most senior leaders - including Heads of State - can be brought to account. This further compels national jurisdictions to act in relation to the commission of international crimes.

While each of these processes may have had varying degrees of "success" - part of the evolution of this process requires appropriate procedural safeguards to ensure an absolutely fair trial (which has not always been carried through in practice $)^{50}$ - the point is that it would have been unthinkable even 15 years ago that leaders or former leaders such as these would ever have faced trial in such a public forum.

It is, therefore, important to recognise that the particular case with which the ICC is currently involved - that of President Bashir of Sudan - is not unique. On the contrary, there is an undeniable and irreversible trend towards recognising and facilitating the accountability of Heads of State and prosecuting them in appropriate circumstances. The culture of absolute impunity that had prevailed for decades no longer exists.

\section{$B$ Legal Dimensions}

These developments follow from the answer that has emerged to a fundamental question: how does the prosecution of a Head of State fit in with the basic principles of Head of State immunity that have long been recognised at international law? After all, as was noted by the International

49 See "Argentine ex-leader goes on trial" (3 November 2009) BBC News <http://news.bbc.co.uk>.

50 For example, the trial of Saddam Hussein was a flawed process. The Supreme Iraqi Criminal Tribunal lacked several fundamental protections to which accused are entitled under international human rights principles. One startling example among many was that there was no requirement of guilt to be proven "beyond reasonable doubt". Rather, it was sufficient that the Tribunal was "satisfied" on the evidence that an accused was guilty. Equally troubling was the fact that the Dujail and Genocide trials were marked by governmental interference (including the replacement of some judges seen as being too lenient towards Saddam), the murder of several defence lawyers, the involvement of inexperienced judges, chaotic scenes within the court room, allegations of bribery of and perjury by prosecution witnesses, allegations of forgery of prosecution evidence and allegations of torture made by the accused. 
Court of Justice in the Arrest Warrant case: "[c]ertain holders of high-ranking office in a State, such as the Head of State, ... enjoy immunities from jurisdiction in other States, both civil and criminal." 51

However, like much of international law, this principle continues to evolve in reaction to changing circumstances and approaches to international crimes. Indeed, in the Arrest Warrant case, the International Court of Justice went on to make it clear that, to the extent that Head of State immunity from jurisdiction did apply to incumbent State officials (in that case the Foreign Minister), this did not amount to impunity in respect of any crimes they may have committed. The Court emphasised that "[i]mmunity from criminal jurisdiction and individual criminal responsibility are quite separate concepts." 52

Moreover, in the House of Lords decision in Pinochet, several of the Law Lords expressed the strong view that there are certain actions - for example torture - perpetrated by individuals in the position of a Head of State that could never be regarded as something to which Head of State immunity would apply. For example, as Lord Browne-Wilkinson noted: ${ }^{53}$

Can it be said that the commission of a crime which is an international crime against humanity and jus cogens is an act done in an official capacity on behalf of the state? I believe there to be strong ground for saying that the implementation of torture as defined by the Torture Convention cannot be a state function.

These conclusions are premised on the legal reality that the prosecution of a Head of State relates solely to the accountability of the individual concerned. The State is not on trial, even though some might regard a Head of State as the practical representation of an abstract entity known as the State, who is recognised as representative of that State by virtue of his or her office.

Whilst at first glance such an assertion may seem like an attractive argument, the alternate approach that has emerged under international law is straightforward. International criminal law has, at least thus far, developed on the basis that individuals, rather than States, commit crimes. ${ }^{54}$ The

51 Case Concerning the Arrest Warrant of 11 April 2000 (Democratic Republic of Congo v Belgium) (Judgment) [2002] ICJ Rep 3 at 21-22.

52 Ibid, at 25.

$53 R v$ Bow Street Metropolitan Magistrate and others, Ex Parte Pinochet Ugarte (Amnesty International and others intervening) (No 3) [2000] $1 \mathrm{AC} 147$ at 203.

54 There have been attempts to incorporate the concept of an international crime committed by a State into international legal documents. In 1949, the United Nations General Assembly (UNGA) asked the International Law Commission (ILC) to work on the task of formulating draft "Articles on the Responsibility of States for Internationally Wrongful Acts". In 1976, on the basis of the then Special Rapporteur's fifth report, the ILC adopted inter alia draft article 19 into the document. This draft article proposed that a distinction be drawn between two different types of internationally wrongful acts that could 
prosecution of an individual, no matter what his or her official capacity may be, relates to actions perpetrated by that person. Claims by some Heads of State, who have faced courts of law, ${ }^{55}$ that their trial represents a legal indictment of an entire State, or even particular elements of the community, are misconceived. The trial rather relates to a determination of the guilt or innocence of the individual(s) facing the charges.

The judgment of the Nuremberg Military Tribunal represents the traditional view in this regard, rejecting as it did the argument submitted by the accused that individuals could not be held responsible for "acts of State". In an oft-quoted passage, the Nuremberg Military Tribunal stated: ${ }^{56}$

That international law imposes duties and liabilities upon individuals as well as upon States has long been recognized. ... Crimes against international law are committed by men, not abstract entities, and only by punishing individuals who commit such crimes can the provisions of international law be enforced.

Both the Arrest Warrant and Pinochet cases involved situations where one State was attempting to prosecute, within its national courts, a senior official or Head of State from another State. It is in this context that the concept of Head of State immunity had emerged in the first place, as a consequence of the respect for a State's sovereignty. Even then, these cases illustrate that this immunity principle would not represent an absolute bar to prosecution of such persons.

give rise to the responsibility of a State under international law - international crimes and international delicts. An international crime was defined as:

An internationally wrongful act which results from the breach by a State of an international obligation so essential for the protection of fundamental interests of the international community that its breach is recognized as a crime by that community as a whole constitutes an international crime.

Draft article 19 gave rise to much controversy among some States, as well as commentators and various members of the ILC itself, some of whom argued that it promoted the idea of collective responsibility of the entire population of a State for the actions of their leaders, as well as the notion of collective punishment. In the end, draft article 19 was not included in the version of the articles that was adopted by the ILC in 2001 and noted by the UNGA later that year: see Resolution on the Responsibility of States for Internationally Wrongful Acts GA Res 56/83, A/Res/56/83 (2001).

55 For example, in his trial before the ICTY, Slobodan Milošević made several serious counterclaims against the North Atlantic Treaty Organization, labelling their actions during "Operation Allied Force", which was conducted against the Federal Republic of Yugoslavia from 24 March to 9 June 1999, as constituting "monstrous crimes" and "crimes of genocide ... crimes against humanity and war crimes". He argued that his trial represented a trial of all Serbian people and his tactics struck a chord with many Serbs, particularly those who saw themselves as victims of the events that subsequently unfolded in the Federal Republic of Yugoslavia: see Daniel Simpson "Serbs refuse to accept blame for war crimes" Sydney Morning Herald (Sydney, 10 August 2002) at 21. For an assessment of "Operation Allied Force" and the subsequent investigation into this campaign conducted at the request of the Prosecutor of the ICTY, see Steven Freeland "The Bombing of Kosovo and the Milosevic Trial: Reflections on some Legal Issues" [2002] Aust ILJ 150.

56 Judgment of the International Military Tribunal, Trial of the Major War Criminals 1 October 1946, reprinted in "Judicial Decisions Involving Questions of International Law" (1947) 41 AJIL 172 at 221. 
As noted above, the position is, if anything, even more straightforward in the case of the prosecution of a Head of State by an international(ised) criminal tribunal or court. Here, the reciprocal basis for State sovereignty is not applicable. The prosecution is not being undertaken by a State and, in any event, any notion of Head of State immunity is simply not relevant, given the express mandate that these institutions have been given.

Furthermore, the development of concepts such as command and superior responsibility ${ }^{57}$ and perhaps to a lesser degree given the confusion with which it is sometimes applied ${ }^{58}$ - joint criminal enterprise, in the jurisprudence of the ad hoc international criminal tribunals, makes it possible for persons to be directly prosecuted for committing the relevant crimes (as opposed to, say, aiding and abetting the commission of such crimes) even though they may not have "pulled the trigger". This will typically describe the situation of a Head of State, who will almost never be physically involved in the actual fighting, but may be the supreme military commander, or may exercise a superiorsubordinate relationship with military officers and personnel, or be engaged in detailed planning discussions with them about proposed combat strategies and goals.

\section{Political Dimensions}

As referred to above, the issue of prosecuting a Head of State is highly sensitive and, by its very nature, heavily influenced by politics. Despite the (generally) positive steps made by the Nuremberg Military Tribunal (in particular) and the Tokyo Military Tribunal regarding the formulation of principles of international criminal law and the foundations towards a process of judicial

57 The notion of command or superior responsibility has been well established in the jurisprudence of the ad hoc tribunals. For a detailed discussion of the position under the ICTY Statute, see for example The Prosecutor v Tihomir Blaškić (Judgment) (3 March 2000) IT-95-14-T (Trial Chamber, ICTY); compare The Prosecutor v Tihomir Blaškić (Judgment) (29 July 2004) IT-95-14-A (Appeals Chamber, ICTY).

58 While it is beyond the scope of this article to discuss the concept of joint criminal enterprise in any detail, in broad terms, it has regularly been used in the jurisprudence of the ad hoc tribunals as a way of confirming the criminal responsibility of an accused who may not have been physically involved with every aspect of those acts that constituted the relevant crime. In 1999, the ICTY Appeals Chamber identified various "categories" of joint criminal enterprise as being "firmly established in customary international law": The Prosecutor v Duško Tadić (Judgment) (15 July 1999) IT-94-1-A (Appeals Chamber, ICTY) at [220]. However, since that time, there has been a lack of consistency and certainty in relation to the application of the joint criminal enterprise concept by the ad hoc tribunals: see Steven Freeland "Commentary on Decision on Motion for Acquittal Pursuant to Rule 98 Bis, The Prosecutor v Radoslav Brdjanin, Case No IT-99-36-T, T Ch, 28 November 2003" in André Klip and Göran Sluiter (eds) Annotated Leading Cases of International Criminal Tribunals, Volume XV: The International Criminal Tribunal for the Former Yugoslavia 2003 (Intersentia, Antwerpen, 2008) 129. This uncertainty as to the precise scope of the joint criminal enterprise concept has been further exacerbated by the early jurisprudence of the ICC: see ICC Decision on the confirmation of charges (Public Redacted Version) (The Prosecutor v Thomas Lubanga Dyilo) (Case No ICC-01/04-01//06, Pre-Trial Chamber I, 29 January 2007) at [317]-[348], where the Pre-Trial Chamber dissociates itself from the jurisprudence of the ad hoc tribunals regarding the joint criminal enterprise concept, and instead accepts a narrower concept of "co-perpetration". 
accountability at the international level - including for Heads of State, it would take almost another 50 years until the next international criminal tribunals were to be established. ${ }^{59}$

There had been some suggestion, up until the early 1950s, that a permanent international criminal court should be established, ${ }^{60}$ either as a separate institution, or as part of a treaty regime focused on particular crimes. In the aftermath of the horrors of World War II, the 1948 Genocide Convention, which, as noted above, allowed for the prosecution of Heads of State, provided that: ${ }^{61}$

Persons charged with genocide or any of the other acts enumerated in article III shall be tried by a competent tribunal of the State in the territory of which the act was committed, or by such international penal tribunal as may have jurisdiction with respect to those Contracting Parties which shall have accepted its jurisdiction.

In the same resolution in which it approved the text of the 1948 Genocide Convention, the UNGA expressed the view that, over time, there would evolve an "increasing need of an international judicial organ for the trial of certain crimes under international law". 62 Accordingly, it invited the ILC to: ${ }^{63}$

... study the desirability and possibility of establishing an international judicial organ for the trial of persons charged with genocide or other crimes over which jurisdiction will be conferred upon that organ by international conventions.

Acting on this invitation, the ILC quickly concluded that the establishment of an international court to try persons charged with genocide or other crimes of similar gravity was both desirable and possible. The UNGA then established a committee to prepare proposals relating to the establishment of such a court. ${ }^{64}$ The committee prepared draft statutes in 1951 and again in 1953. However, at that time, all work on the drafting of a statute for any such proposed court was halted indefinitely. ${ }^{65}$

59 The first of these, the ICTY, was only established in 1993: see SC Res 827, above n 1.

60 James Crawford "The drafting of the Rome Statute" in Sands, above n 21, 109 at 110.

611948 Genocide Convention, above n 29, art 6.

62 Prevention and Punishment of the Crime of Genocide: Study by the International Law Commission of the Question of an International Criminal Jurisdiction GA 260 (III) B at [2], A/Res/3/260 B (1948).

63 Ibid, at [3]

64 International Criminal Jurisdiction GA Res 489 (V), UN GOAR, 5th sess, 320th plem mtg (1950) at [1]. The Committee was comprised of representatives of 17 States - Australia, Brazil, China, Cuba, Denmark, Egypt, France, India, Iran, Israel, The Netherlands, Pakistan, Peru, Syria, the United Kingdom, the United States of America and Uruguay.

65 See Draft Code of Offences Against the Peace and Security of Mankind GA Res 897 (IX), UN GOAR, 9th sess, 504th plen mtg (1954) at [3]; International Criminal Jurisdiction GA Res 898 (IX), UN GOAR, 9th sess, 512th plen $\operatorname{mtg}(1954)$ at [2]. 
Instead, the spectre of Realpolitik emerged, as the onset of the Cold War meant that it was no longer possible for the international community to find the common will to build upon the foundations laid by the Nuremberg and Tokyo Military Tribunal processes. There were also other very strong political forces at work, as States sought to cling to the international law principle of non-intervention, as elaborated in Article 2(7) of the United Nations Charter. ${ }^{66}$

It was thus that an era of "impunity for the perpetrators of these [international] crimes" 67 took hold, which would not be challenged to any significant degree until after the fall of the Berlin Wall in November 1989. Atrocities took place in countries around the globe during this period including in the Soviet Union, Uganda, Nigeria, Argentina, Bangladesh, East Timor, Algeria, Cambodia and Iraq, to name but a few examples. However, none of these were either investigated to any significant degree, let alone punished, by a court of law. Indeed, it has been estimated that approximately 170 million people were killed during the period 1945 to 1990 , with little if any accountability. ${ }^{68}$ In certain respects, it was as if the important treaties developed during this time, such as the 1948 Genocide Convention, were treated as an end in themselves - sitting on the shelf with little tangible action to address these gross violations of human rights in a practical sense.

There were only relatively minor steps taken in this regard by the international community during this lengthy period of (virtual) inaction. A treaty was finalised specifying that statutory limitations under national law were inappropriate and should not be applicable to war crimes and crimes against humanity, which were described as "among the gravest crimes in international law". ${ }^{69}$ Yet, there was an almost total lack of political will by most countries to prosecute, within their respective national court systems, individuals suspected of committing such crimes. The prosecution and subsequent conviction of Otto Adolf Eichmann by the Israeli District Court in 1961 (affirmed by the Israeli Supreme Court the following year) was one of the very few exceptions to this failure to act. $^{70}$

66 Charter of the United Nations, art 2(7) inter alia provides:

Nothing contained in the present Charter shall authorize the United Nations to intervene in matters which are essentially within the domestic jurisdiction of any state or shall require the Members to submit such matters to settlement under the present Charter.

67 Rome Statute, above n 13, preamble at [5].

68 See M Cherif Bassiouni "The Normative Framework of International Humanitarian Law: Overlaps, Gaps and Ambiguities" (1998) 8 Transnat'l L and Contemp Probs 199 at 203-204.

69 Convention on the Non-Applicability of Statutory Limitations to War Crimes and Crimes against Humanity (opened for signature 26 November 1968, entered into force 11 November 1970), preamble at [4].

70 Attorney-General of the Government of Israel v Eichmann (1961) 36 ILR 5 (DC Jerusalem). Eichmann was prosecuted under Israeli law (1951 Nazi and Nazi Collaborators (Punishment) Law) for war crimes, crimes against the Jewish people (the definition of which was modelled on the definition of genocide in the 1948 Genocide Convention) and crimes against humanity. He was convicted by the District Court of Jerusalem 
The lack of credible action on the part of national jurisdictions was subsequently acknowledged in the UNGA, which drew attention to the fact that "many war criminals and persons who have committed crimes against humanity are continuing to take refuge in the territories of certain States and are enjoying protection". ${ }^{71}$

The sole attempt to bring a Head of State to justice during this period was an abject failure, not only by reason of the fact that it was ineffectual, but also because of the process that was implemented. A death sentence in absentia was pronounced in 1979 on Khmer Rouge leader Pol Pot and his Deputy Prime Minister by a Revolutionary People's Tribunal established by the Vietnamese authorities, following their invasion of Cambodia. However, this had not been preceded by any semblance of due process and was not recognised internationally as a credible trial. In any event, the accused were by that time already safely in Thailand, where their protection was also supported by both China and the United States, thus rendering futile any attempt to have them extradited back to Cambodia.

The consequences of such political influences have meant, in the case of Cambodia, the implementation of "delayed justice", which in itself has been the cause of criticism. ${ }^{72}$ The tortured political negotiations that led to the eventual establishment of the Extraordinary Chambers in the Courts of Cambodia ${ }^{73}$ have meant that a criminal prosecution process has only recently begun in

and sentenced to death. His appeal to the Supreme Court of Israel was dismissed: Eichmann v AttorneyGeneral of the Government of Israel (1962) 36 ILR 277. In 1987, Klaus Barbie, who had been the head of the Gestapo in Lyon from November 1942 to August 1943 and was known as the "Butcher of Lyon", was convicted by the Rhône Cour d'assises of 17 counts of crimes against humanity. His appeal was dismissed by the French Court of Cassation: Fédération Nationale des Déportés et Internés Résistants et Patriotes and Others $v$ Barbie (1988) 100 ILR 330.

71 Resolution on the Question of the Punishment of War Criminals and of Persons who have Committed Crimes against Humanity GA Res 2712 (XXV), UN GOAR, 25th sess, 1930th plen mtg (1970) at [1].

72 See for example Elizabeth Becker "When justice is delayed" International Herald Tribune (New York, 1415 March 2009) at 7.

73 It was not until the late 1990s that any serious suggestion of bringing the Khmer Rouge to account before a credible legal process was initiated in Cambodia. However, the subsequent wrangling between the Cambodian government and the United Nations as to the precise structure of the Extraordinary Chambers in the Courts of Cambodia impinged on the (real and, or, perceived) integrity of the process, even before it began its operations in earnest. The government of Cambodia had earlier rejected the recommendation of a United Nations appointed group of experts that an international tribunal be established to try those responsible for crimes of genocide and crimes against humanity in the period 1975-1979. China had also publicly opposed the establishment of an international tribunal, thereby raising the spectre of a UNSC veto. The situation was further complicated by the fact that Cambodian Prime Minister Hun Sen had been a Khmer Rouge official during the 1970s. Eventually, after over three and a half years of tortuous negotiations, an agreement was reached in June 2003 between the United Nations and the Cambodian government for the establishment of an internationalised court to deal with the issue. The agreement came into force in April 2005, 30 years after the Khmer Rouge had seized power in Cambodia. 
relation to the "killing fields" of the mid-1970s (a time frame that, by analogy, would have seen the Nazi war leaders prosecuted only in 1975).

In the meantime, a whole generation of Cambodians has been born, many of whom have been led to believe that the genocide perpetrated by the Khmer Rouge was instead committed by the Vietnamese or the Chinese - misinformation that has been encouraged by the current government, many of whom are former Khmer Rouge cadres. ${ }^{74}$ Equally disconcerting are the reports that have emerged of corruption and government influence that are further hindering the work of the internationalised tribunal that was finally established. ${ }^{75}$ Moreover, whatever the eventual outcome of any proceedings that take place before the Chambers, reliance on this obviously politically manipulated process so long after the events to which it relates - with no other possible mechanism, either on a regional or international basis, to deal in a timely fashion with the political leaders who perpetrated these crimes - is not satisfactory.

\section{THE ROLE OF THE INTERNATIONAL CRIMINAL COURT}

\section{A Establishment}

As is well known, the ICC was established on 1 July 2002, following the ratification of the Rome Statute by 60 States. $^{76}$ The Court has been given the mandate to play a role when specific international crimes have (allegedly) been committed. As a permanent court, it differs from the ad hoc international criminal tribunals, which were set up as United Nations subsidiary organs in response to specific events and were always intended to have a limited life-span, as is indicated by the formulation by the UNSC of the Completion Strategy that each is currently operating under. ${ }^{77}$

By contrast, the ICC is a permanent institution, established under a treaty and, as such, independent of the United Nations, although there is clearly an ongoing relationship between the two institutions on several key issues, which impacts directly upon the question of prosecuting Heads of State. The ICC has the power to exercise its jurisdiction with respect to circumstances that

74 Becker, above n 72, at 7.

75 See for example Michael Saliba "Allegations of Corruption at ECCC: An Overview" (2009) Cambodia Tribunal Monitor <www.cambodiatribunal.org $>$.

76 See Rome Statute, above n 13, art 126(1). There are currently 111 State parties.

77 See for example Resolution on the International Criminal Tribunal for the former Yugoslavia and International Criminal Tribunal for Rwanda SC Res 1503, S/RES/1503 (2003), which refers in preamble at [7] to the "ICTY Completion Strategy" and in preamble at [8] to the "ICTR Completion Strategy". UNSC Resolution 1534 emphasises the "importance" of each of the ad hoc tribunals implementing their respective completion strategies and calls upon the Tribunals to "plan and act accordingly": Resolution on the International Criminal Tribunal for the former Yugoslavia and International Criminal Tribunal for Rwanda SC Res 1534 at [3], S/RES/1534 (2004). However, it remains to be seen whether the ad hoc tribunals will be able to adhere to the timetable specified in their respective completion strategies for the completion of their work. 
may occur in the future - that is, at any time after the Rome Statute came into force. Thus, unless the Assembly of States Parties to the Rome Statute decides to completely alter its nature or focus, the ICC will remain in place for the long-term.

In this sense, the ICC represents an important guardian of those values and norms that are accepted universally among the international community. As the then United Nations SecretaryGeneral, Kofi Annan, put it following the agreement of delegates at the 1998 Rome Conference to adopt the Rome Statute, ${ }^{78}$ the Court's creation is "a gift of hope to future generations, and a giant step forward in the march towards universal human rights and the rule of law". ${ }^{79}$

Not only is this important in and of itself; it also reaffirms the interrelationship between the maintenance of international peace and security - one of the principal purposes of the United Nations - and the respect for fundamental human rights. Indeed, the UNSC has acknowledged that: ${ }^{80}$

... peace and security, development and human rights are the pillars of the United Nations system and the foundations for collective security and well-being, and ... in this regard ... development, peace and security and human rights are interlinked and mutually reinforcing.

\section{B Jurisdiction}

The ICC, like any specifically established court, can only operate within the confines of the jurisdiction that it has been granted. The mandate of the ICC is "complementary" to that of States, meaning that the Court is to be regarded as a court of last resort. ${ }^{81}$ In essence, this means that primary responsibility for the prosecution of these crimes lies with States. This in itself demonstrates a shift in emphasis from the culture of impunity that had existed before the 1990s, during which time it was evident that States were very reluctant to try their own nationals (let alone

78 The United Nations Diplomatic Conference of Plenipotentiaries on the Establishment of an International Criminal Court (1998 Rome Conference) was convened and took place from 15 June to 17 July 1998, "with a view to finalising and adopting a convention on the establishment of an international criminal court": see Resolution on the Establishment of an International Criminal Court GA Res 52/160 at [3], A/RES/52/160 (1997).

79 See United Nations "Secretary-General says Establishment of International Criminal Court is Major Step in March Towards Universal Human Rights, Rule of Law" (press release L/2890, 20 July 1998).

80 Resolution on the Protection of civilians in armed conflict SC Res 1674 preamble at [3], S/RES/1674 (2006).

81 See Rome Statute, above n 13, arts 17-18. For a discussion of the principle of "complementarity" as it is applied in the Rome Statute, and some of the uncertainties to which its implementation may give rise, see Alexis Goh and Steven Freeland "Report on the Rome Statute and the International Criminal Court" in Gabriël A Moens and Rodolphe Biffot (eds) The Convergence of Legal Systems in the 21st Century - An Australian Approach (CopyRight Publishing, Brisbane, 2002) 285 at 290-296. 
Heads of State) for war crimes, and even more so where crimes against humanity or genocide were concerned.

The ICC has jurisdiction with respect to the following crimes committed after 1 July $2002: 82$

- $\quad$ genocide;

- $\quad$ crimes against humanity;

- war crimes;

- the [only recently defined] crime of aggression.

Articles 12 and 13 of the Rome Statute specify the "[p]reconditions to the exercise of jurisdiction" and "exercise of jurisdiction" by the Court respectively. In summary, the ICC can exercise its jurisdiction in relation to these crimes in the following circumstances:

- where an (alleged) crime has been committed on the territory of a State party to the Rome Statute ${ }^{83}$

- where a national(s) of a State party to the Rome Statute is alleged to have committed a crime ${ }^{84}$

- $\quad$ where a situation in which a crime(s) "appears to have been committed" has been referred to the Prosecutor of the ICC by the UNSC acting under Chapter VII of the United Nations Charter; ${ }^{85}$ or,

- where a non-State party to the Rome Statute lodges a declaration with the Registrar of the ICC, accepting the jurisdiction of the Court with respect to the "crime in question". ${ }^{86}$

\section{Relationship between the ICC and the UNSC}

As noted, although it is formally not part of the United Nations system, the ICC has a significant relationship with various part of the United Nations, most notably the UNSC. It is this relationship that is particularly relevant in the Darfur situation, and which has facilitated the indictment of the

82 Rome Statute, above n 13, art 5(1).

83 Ibid, art 12(2)(a).

84 Ibid, art 12(2)(b).

85 Ibid, art 13(b). This referral mechanism was implemented by the UNSC in relation to the situation in Sudan, which has ultimately led to an arrest warrant being issued against President Bashir: see Reports of the Secretary-General on the Sudan SC Res 1593, S/RES/1593 (2005).

86 Rome Statute, above n 13, art 12(3). See also Steven Freeland "How Open Should the Door Be? Declarations by non-States Parties under Article 12(3) of the Rome Statute of the International Criminal Court" (2006) 75 Nord J Intl L 211. 
current Head of State of Sudan, since the situation in Darfur was referred to the Prosecutor of the ICC by the UNSC pursuant to Article 13(b) of the Rome Statute.

Also as noted, Article 16 of the Rome Statute provides for the deferral of an investigation or prosecution by the ICC upon the request of the UNSC. This deferral expressed to continue is for a 12-month period, subject to renewal by the UNSC under the same conditions. The deferral mechanism has been implemented in the past in reaction to concerns about the Court raised by the United States in particular, ${ }^{87}$ but it has not been used for several years. However, both the African Union and the Organisation of Islamic States are attempting to convince UNSC member States to again use it in relation to the Bashir case, at the same time maintaining their call for their respective member States not to cooperate with various ICC processes, in particular those concerned with the arrest and surrender of President Bashir. ${ }^{88}$

\section{Goals and Mandate}

Regarding the question of whether the ICC should be involved in the prosecution of Heads of State in appropriate circumstances (remembering, as noted above, that the official capacity of a person is not relevant to the Court), it is important to recall its mandate and the context within which it has been established. These are articulated in the preamble of the Rome Statute as follows: ${ }^{89}$

Affirming that the most serious crimes of concern to the international community as a whole must not go unpunished and that their effective prosecution must be ensured by taking measures at the national level and by enhancing international cooperation,

Determined to put an end to impunity for the perpetrators of these crimes and thus to contribute to the prevention of such crimes,

Recalling that it is the duty of every State to exercise its criminal jurisdiction over those responsible for international crimes.

More generally, the whole concept of international justice is itself a very complex issue. The ICC represents another (albeit significant) development in the ongoing evolution of this process of justice. Yet, this is an ongoing process and we are still in a relatively embryonic stage as far as determining how the establishment of this permanent mechanism of international justice will, if at

87 For an overview of the various actions taken by the United States after the Rome Statute had been finalised, including the use of the art 16 deferral mechanism, see Steven Freeland and Michael Blissenden "The International Criminal Court: Politics, Justice and Impunity" in Australian New Zealand Society of International Law International Governance and Institution: What Significance for International Law? (Proceedings of the 11th Annual Meeting, Wellington, 2003) 319.

88 See for example African Union Report on the Activities of the African Regional Organisation of the International Trade Union Confederation AU Doc LSC/EXP/12c (VII) (2009) at [36].

89 Rome Statute, above n 13, preamble at [4]-[6]. 
all, impact upon actions by future Heads of State. In this regard, it is of vital importance that those involved in this evolutionary process try to gain an understanding based on experience and events as they unfold, as to precisely what it is that the international community and civil society are trying to achieve as we develop the various tools of international justice.

Although this is far too simplistic, and it is far too early in the life of the ICC to ascribe in detail any hard and fast factors, I suggest that one way to approach this issue is to perhaps think of the "goals" of international justice, and the imposition of appropriate modes of punishment, ${ }^{90}$ in terms of the following "micro" and "macro" criteria:

- micro goals

- guilt or innocence of the accused

- individual responsibility

- revenge

- $\quad$ voice for victims

- individual memory

- $\quad$ closure and satisfaction

- macro goals

- reconciliation

- retribution

- reparation

- deterrence and prevention

- $\quad$ peace and justice

- historical record

- collective memory

- $\quad$ transparent process

90 See for example The Prosecutor v Zlatko Aleksovski (Judgment) (24 March 2000) IT-95-14/1-A (Appeals Chamber, ICTY) at [185] and the corresponding footnotes. The Prosecutor at the Nuremberg Military Tribunal, Robert H Jackson, argued that:

The satisfaction of instincts of revenge ... for the sake of retribution are obviously the least sound basis of punishment. If punishment is to lead to progress, it must be carried out in a manner which world opinion will regard as progressive and as consistent with the fundamental morality of the Allied case.

This was quoted in William A Schabas "Sentencing by International Tribunals: A Human Rights Approach" [1997] 7 Duke J Comp and Intl L 461 at 500. There have been numerous decisions by the ad hoc tribunals that elaborate on the goals of the international criminal justice system that has been established: see for example The Prosecutor v Dario Kordić and Mario Čerkez (Judgment) (17 December 2004) IT-95-14/2-A (Appeals Chamber, ICTY) at [1078] and [1081] and the corresponding footnote; The Prosecutor v Milan Babić (Sentencing Judgment) (29 June 2004) IT-03-72-S (Trial Chamber, ICTY) at [45], cited with approval by the ICTY Appeals Chamber in The Prosecutor v Tihomir Blaškić, above n 57, at [678]. 
Naturally, there may be other goals, and some of those suggested above may themselves not be appropriate for certain situations. No doubt also, simply providing a list of possible goals may raise more questions than it does provide answers at this stage. However, the reality is that, despite the momentum generated by the establishment of the ICC, we are still in the relatively early stages of development in terms of establishing the most appropriate methodologies of achieving the goals of international criminal justice. It is clear that this will be the subject of future research, particularly addressing the fundamental issue of how to "measure" the "effectiveness" of the various models of international criminal justice. This question has not previously been the subject of systematic and comprehensive comparative research and will depend upon those "performance indicators" that are considered as important in the context of the particular court or tribunal concerned.

Undoubtedly, it is important to determine the most appropriate "success" criteria by which the performance of a particular court or tribunal can be analysed. It might be difficult to reach definitive conclusions while a specific court or tribunal is still operating, particularly if the relevant conflict to which it relates remains ongoing. Yet, as the various tribunals reach the "shelf-life date" of their judicial activities - as, for example, the Serious Crimes Panels for Timor-Leste did in 2005 and the ICTY and ICTR (in theory) are required to by 2010 - it will ultimately become easier to consider their impact within a broader context. Only then will it be possible to attempt to match goals with results.

In terms of the ICC, this is currently not possible, at least in terms of any particular detail. Yet, I would hasten to add that the prosecution of a Head of State should and would, in appropriate circumstances, fall squarely within the general and specific goals of courts like the ICC. Or put another way, such a prosecution would not be inconsistent with the role that the international community has bestowed upon the ICC.

\section{E Criteria of "Success"}

As noted above, coupled with any specific goals of international justice that may be attributed to the ICC is the question of how history will judge whether this ongoing process of the internationalisation of justice has been, is and will be a "success", particularly in view of the undoubted challenges that the ICC faces. Yet, it is not at all clear as to how one could or should evaluate the "success" of international criminal justice. There are, in my opinion, various criteria by which one might attempt to measure the "performance" of the mechanisms of international justice, ${ }^{91}$ although in the end the true litmus test of the effectiveness of international justice will, ironically, centre around the extent to which States themselves are willing to take on the responsibility to

91 It is beyond the scope of this article to expand in detail upon this aspect of international criminal justice: for a discussion of these suggested criteria, see Steven Freeland "The Effectiveness of International Criminal Justice" (2008) 1 Legal Studies - Lifeline (Special Edition) 1. 
ensure a greater accountability for those persons - including (former) Heads of State - who have been responsible for gross violations of human rights.

In any event, whatever the most appropriate criteria for measuring success, a simple question must always be asked: would these criteria and goals be satisfied simply by the prosecution of "foot soldiers", rather than those who have the "greatest responsibility"92 for the commission of international crimes, whoever they may be and whatever their official capacity is? I would strongly argue that the answer to this question is self-evident.

\section{THE ROAD FORWARD}

In the end, the effectiveness of international criminal justice will largely depend on the efforts of States to demonstrate the requisite political will - backed by tangible resources and action necessary to allow for proper accountability of those who commit serious crimes. Courts like the ICC have a vital role to play in this process, but their creation is not the panacea that will stop these atrocities from taking place. The ICC is just one (albeit very important) cog in an ever more complex matrix of mechanisms that must be implemented if, in the future, the world is to see justice, in the broader sense, for all. There is no doubt that this also involves much more concerted action on the part of States.

Yet, it is clear that progress has been made and the prosecution of Heads of State is an integral element in the internationalisation of justice and the end of the era of impunity. Indeed, the concept of the "Pinochet syndrome" has now entered modern day lexicon ${ }^{93}$ - where the senior political and military leaders of today and tomorrow can no longer ignore the rule of law or the reach of this system of internationalised criminal justice, by assuming that they will never be brought to account.

In this sense, the prosecution of Heads of State in appropriate circumstances is entirely justified and justifiable. It is clearly consistent with the goals of national and international justice. It is clearly within the principles of international law. It is clearly within the mandate of the various international and internationalised courts and tribunals (including the ICC) that have been established. It is clearly in keeping with the desire of civil society to ensure that the culture of impunity, which had existed for many years and had seen countless deaths, does not re-emerge. And, despite what some may argue, it is not an isolated occurrence, but rather is part of a growing and irreversible trend at both the international and national levels.

92 See for example the Statute of the Special Court for Sierra Leone, above n 39, art 1(1), which mandates the Court with the "power to prosecute persons who bear the greatest responsibility for serious violations of international humanitarian law and Sierra Leonean law committed in the territory of Sierra Leone since 30 November 1996" (emphasis added).

93 See for example Barbara Crossette "The World; Dictators Face the Pinochet Syndrome" The New York Times (New York, 22 August 1999) <www.nytimes.com>. 
Perhaps most poignant of all are the words from a current Head of State. In 2007, The Economist quoted Libya's President Muammar Qaddafi - the Chair of the African Union from 2 February 2009 to 31 January 2010 - when he anxiously responded in the following terms to the arrest of his former protégé Charles Taylor: "[t]his means that every head of state could meet a similar fate. It sets a serious precedent". ${ }^{94}$

Let us all hope that President Qaddafi is indeed correct.

94 "How the mighty are falling" The Economist (London, 7 July 2007) at 59. 